\title{
First record of bridal creeper rust, Puccinia myrsiphylli, a classical biocontrol agent of the environmental weed bridal creeper, Asparagus asparagoides, in New Zealand
}

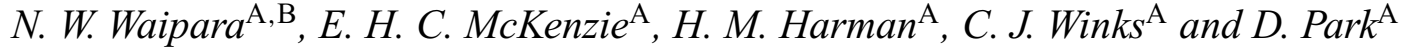 \\ ${ }^{A}$ Manaaki Whenua Landcare Research, Private Bag 92170, Auckland, New Zealand. \\ ${ }^{\mathrm{B}}$ Corresponding author. Email: waiparan@landcareresearch.co.nz
}

Abstract. Puccinia myrsiphylli is reported for the first time on weed infestations of Asparagus asparagoides in New Zealand, where it is concluded to have been introduced either accidentally or autonomously by way of winddispersed spores. A detailed description, illustration and genetic sequence of the specimen are provided.

Bridal creeper Asparagus asparagoides (L.) Druce, also known in New Zealand as smilax, is a scrambling perennial vine that invades forest margins, open woodlands, hedges, and coastal slopes (Roy et al. 2004). It is very competitive, blocking other plants both from sunlight, through its dense canopy, and from access to the soil, through its dense mat of rhizomes and tubers (Esler 2004).

Bridal creeper was originally introduced to Australasia from southern Africa for ornamental cultivation. By the early 1900 s it had noticeably naturalised in New Zealand (Esler 2004), where it has now invaded many natural and productive areas of northern New Zealand and consequently been declared a serious and unwanted plant pest (Roy et al. 2004). In Australia, the plant was first recorded as naturalised in Victoria, and by 1886 it had rapidly spread to become a significant environmental weed in eastern regions of Victoria and New South Wales (Morin et al. 2002). To mitigate the weed's deleterious environmental impacts, a classical biocontrol programme to look for potential agents was initiated in the 1990s (Kleinjan et al. 2004). A leaf rust, Puccinia myrsiphylli G.Winter, commonly referred to as bridal creeper rust, was identified in southern Africa as a suitable agent (Scott and Kleinjan 1991) and was released in Australia in June 2000. An effective programme to augment natural spread of the rust was initiated by community groups and local government and by 2002 the rust had been released at over 250 sites infested with bridal creeper (Morin et al. 2002).

In November 2005, diseased bridal creeper plants infesting barberry (Berberis glaucocarpa) and boxthorn (Lycium ferocissimum) hedgerows were observed on farmland near the International Airport at Mangere, Auckland (Fig. 1). A severe disease outbreak was underway with most plants exhibiting typical infection symptoms of yellow leaf spots on newly infected leaves through to complete dieback and defoliation of plants. Samples were collected and examined, and rust pustules associated with the infection were identified as $P$. myrsiphylli.

Examination of New Zealand material by light microscopy revealed that urediniospores, mounted in anhydrous lactophenol, measured $23-32.5 \times 18-27 \mu \mathrm{m}$ (mean of 40 spores, $27.7 \times 21.4 \mu \mathrm{m})$. These measurements are smaller than those given in the original description (von Thümen 1877; and repeated in Doidge 1926) of 34-40 $\times 26-30 \mu \mathrm{m}$. Teliospores measured $43-77 \times 20-31 \mu \mathrm{m}$ (mean of 40 spores, $56.2 \times 25.4 \mu \mathrm{m}$ ), which is similar to the dimensions of $43-70 \times 17-28 \mu \mathrm{m}$ given by Winter (1884) and Doidge (1926). The measurements obtained for the New Zealand rust are consistent with those found in both Australia and South Africa (L. Morin and A. Wood, pers. comm.), and the original dimensions quoted for the urediniospores are presumably wrong.

Genetic sequencing for the molecular characterisation of P. myrsiphylli was undertaken using the following method. Total genomic DNA was extracted from a sample of leaf tissue infested with mycelia and spores using a QIAGEN DNeasy Plant Mini kit (Qiagen, Valencia, CA) following the manufacturer's protocol. DNA sequence data for the ITS-1, 5.8S and ITS-2 regions was obtained for fungal DNA using the primers ITS1F and ITS4B (Gardes and Bruns 1993). Following PCR, the amplification products were column purified and sequenced in both directions with ITS1F and ITS4B using ABI Big Dye Terminator version 3.1 and analysed on an ABI 3100-Avant Genetic Analyzer. The sequence was compared with sequences in GenBank. Comparison of the New Zealand sample and P. myrsiphylli sequences in GenBank demonstrated that ITS-1, 5.8S and ITS-2 regions were identical. DNA sequence 

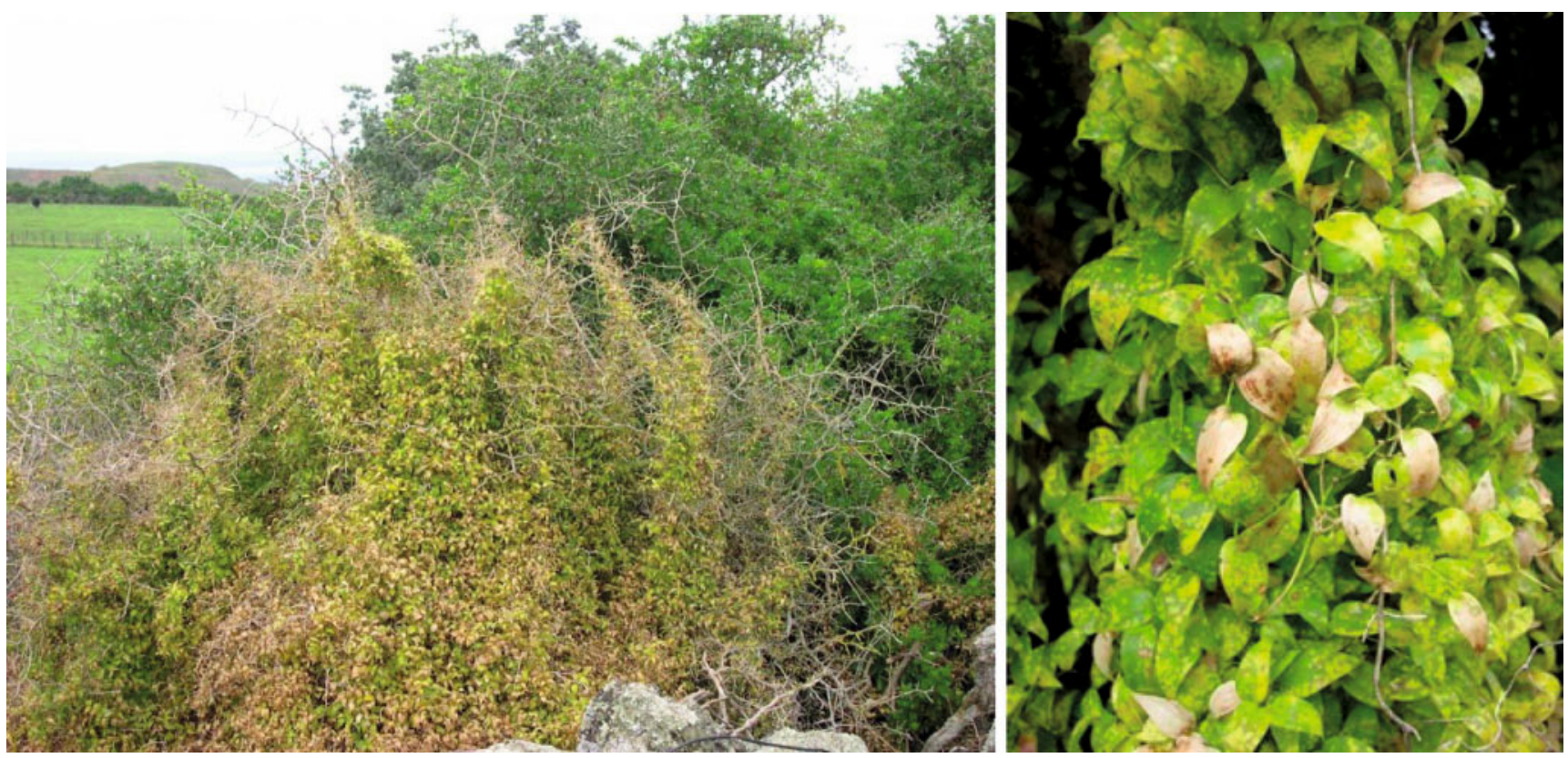

Fig. 1. Puccinia myrsiphylli damaging bridal creeper plants on farmland at Mangere, Auckland, New Zealand: (left) diseased plants infesting a boxthorn hedge; (right) bridal creeper exhibiting symptoms of severe leaf infection.

for ITS region has been deposited in GenBank (accession number, DQ821712).

Surveys and field assessments are now underway to monitor the distribution, spread and impact of $P$. myrsiphylli on bridal creeper populations in New Zealand. Specimens are lodged in the New Zealand Fungal Herbarium (PDD 83934, 83935, 88209, 88212), Landcare Research, Auckland, New Zealand.

\section{Acknowledgements}

The authors acknowledge Dr Louise Morin (CSIRO), Dr Alan Wood (ARC-PPRI South Africa), Drs Peter Johnston and Shaun Pennycook (Landcare Research) for their helpful information and comments on this work. A national collective of regional councils and Department of Conservation provided financial support.

\section{References}

Doidge EM (1926) A preliminary study of the South Africa rust fungi. Bothalia 2, 1-228.

Esler AE (2004) 'Wild plants in Auckland.' (Auckland University Press: Auckland)
Gardes M, Bruns TD (1993) ITS primers with enhanced specificity for basidiomycetes - application to the identification of mycorrhizae and rusts. Molecular Ecology 2, 113-118.

Kleinjan CA, Morin L, Edwards PB, Wood AR (2004) Distribution, host range and phenology of the rust fungus Puccinia myrsiphylli in South Africa. Australasian Plant Pathology 33, 263-271. doi: 10.1071/AP04006

Morin L, Willis AJ, Armstrong J, Kriticos D (2002) Spread, epidemic development and impact of the bridal creeper rust in Australia: summary of results. In 'Proceedings of the 13th Australian Weeds Conference, Australia. 8-13 September 2002'. (Eds H Spafford Jacob, J Dodd, JH Moore) pp. 385-388. (Plant Protection Society of WA Inc.: Perth)

Roy B, Popay I, Champion P, James T, Rahman A (2004) ‘An illustrated guide to common weeds of New Zealand.' 2nd edn. (New Zealand Plant Protection Society: Lincoln)

Scott JK, Kleinjan CA (1991) Bridal creeper (Myrsiphyllum asparagoides) in Australia and developments towards its biological control. Plant Protection Quarterly 6, 116-119.

von Thümen F (1877) Fungi Austro-Africani. V. Flora 60, 407-413.

Winter G (1884) Exotische Pilze. Flora 67, 259-267.

Received 23 June 2006, accepted 21 September 2006 